\section{APSA Names 1999 Centennial and Small Research Grant Winners}

In May, APSA named the winners of the 1999 Centennial and Small Research Grants. The selection committee, composed of members of the APSA Committee on Education and Professional Development and the APSA Research Support Advisory Board, selected 13 of the 53 proposals submitted in this intense competition for research funding. The funded projects represent a range of fields and will be conducted by independent scholars and faculty in colleges and universities that do not award a doctorate degree in political science.

The 1999 Centennial and Small Research Grant winners are:

\section{Centennial Research Grant}

Georgia Duerst-Lahti, Beloit College, "Women's Caucus for Political Science: Organizational History"

\section{Small Research Grant}

Marijke Breuning, Truman State University, "Analogy and Reason: Development Assistance in the Truman Era" Karen Callaghan, University of Massachusetts, Boston, "Liberal Journalists and Liberal Agendas? Testing the Biased Media Hypothesis"

Todd Donovan, Western Washington University, "Public Opinion About Democratic Institutions: Constituencies for Change"

Marni Ezra, Hood College, "A Comparison of Media Coverage in Congressional Primary and General Elections" Scott Frisch, East Carolina University, "An Alternative Measure of Fiscal Consistency"

Timothy Krebs, University of North Carolina, Greensboro, "The Municipal Money Chase: The Nature of Campaign Finance in City Council Elections"

William Hughes and Magdalena Staniek, Southern Oregon University, "Frankenstein Conquers Poland: The Challenge of Coalition Building in Pre-Party Poland"

Mark Rush, Washington and Lee University, "Research and Database Development on the Impact of Redistricting in American and Canadian Electoral Systems"

Lynn Vavreck, Dartmouth College, "Do Attack Ads Help or Hinder Voters? Examining the Effects on Voter Interest,

Participation, and Learning across States in the 1998 Midterm Elections"

Craig Wheeland, Villanova University, “'Empowering the Vision' Ten Years Later: Assessing the Implementation of Rock Hill's Citywide Strategic Plan"

Bruce Wilson, University of Central Florida, "The Motivation for the Consequences of Judicial Reform: Evidence from Costa Rica"

Virginia Walsh, Rutgers University, Newark (Center for Global Change and Governance), "Political, Economic, and Sociological Barriers to Knowledge of Marine Biodiversity."

The Centennial Research Grant, created in 1998 in honor of APSA's upcoming centennial in 2003, provides up to $\$ 1800$ of nonrenewable support for research on a significant element of the history of the discipline of political science, the profession, or the Association. Centennial Grant winners will receive special consideration when submitting articles resulting from their research for publication in PS.

The Small Research Grant program was established in 1984 to make research resources more readily available to individual scholars and political scientists affiliated with institutions without large research budgets. The grant provides up to $\$ 1800$ of nonrenewable support for research in all fields of political science to cover nearly all research expenses, except for travel to professional meetings, secretarial costs, or salary support for the principal investigator.

To be eligible for either the Centennial Grant or the Small Research Grant, applicants must be current APSA members. Additional details about these annual grant competitions may be found online (www.apsanet.org/PS/grants/ resgrant.html).

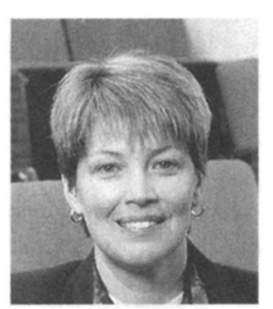

Georgia Duerst-Lahti

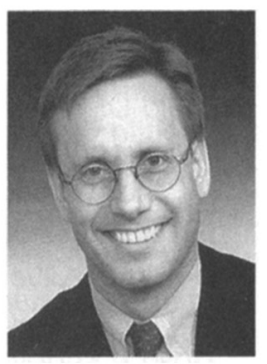

Timothy Krebs

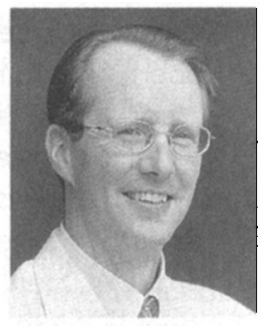

Mark Rush

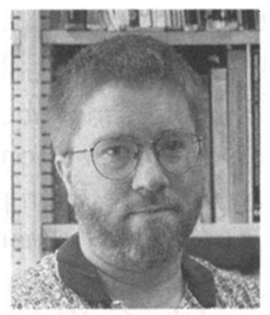

Craig Wheeland

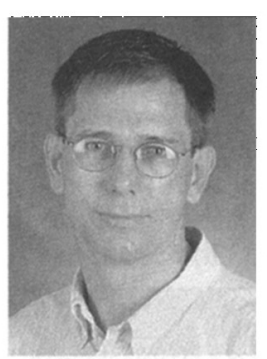

Bruce Wilson

\section{Minority Identification Project Benefits Students, Shows Survey}

APSA's Minority Identification Project, begun in the mid-1980's as a means for attracting talented minority undergraduate students to graduate study in political science and increasing diversity in the political science profession, appears to be succeeding.

Sponsored by a group of 42 "core" schools (mostly large, Ph.D.granting institutions which both provide and recruit the participating students), MID works because a nationwide network of faculty at core and noncore schools (faculty at any college or university are encouraged to recommend participants) begin talking with students as early as their freshman year about careers in political science. The real work of MID is accomplished when undergraduate faculty recommend individual students to leading graduate programs and the programs begin recruiting the recommended students.

For the past several years, surveys have been conducted of MID students to assess the value and effectiveness of the project. This year, the survey was conducted via email for the first time. It was sent in April to 186 students, and by June 15 , a total of 59 completed surveys had been returned. Excluding the 21 undeliverable addresses, the response rate was $36 \%$, which is considerably higher than those of the previous surveys conducted by mail (15\% in 1998, 16\% in 1997). Highlights of the findings include:

1. The project has a positive impact.

- Sixty percent of respondents said their participation in the project positively influenced their decision to pursue graduate study in political science

- Twenty-five percent of the respondents have applied to graduate schools in political science (compared to $14 \%$ in 1998). Of those who graduated before the summer of 1999, 52\% applied (compared to $24 \%$ of spring 1998 graduates). 